Jurnal Health Sains: p-ISSN: 2723-4339 e-ISSN: 2548-1398

Vol. 2, No. 3, Maret 2021

\title{
HUBUNGAN MENGGANTUNG PAKAIAN DAN MEMASANG KAWAT KASA DENGAN KEJADIAN DEMAM BERDARAH DENGUE DI KABUPATEN LANGKAT
}

\section{Syarifah Fadrina, Irnawati Marsaulina dan Nurmaini}

Universitas Sumatera Utara (USU) Medan Sumatera Utara, Indonesia

Email: syarifah.fadrina@gmail.com,irnamarsa@yahoo.com dan nurmainik@yahoo.com

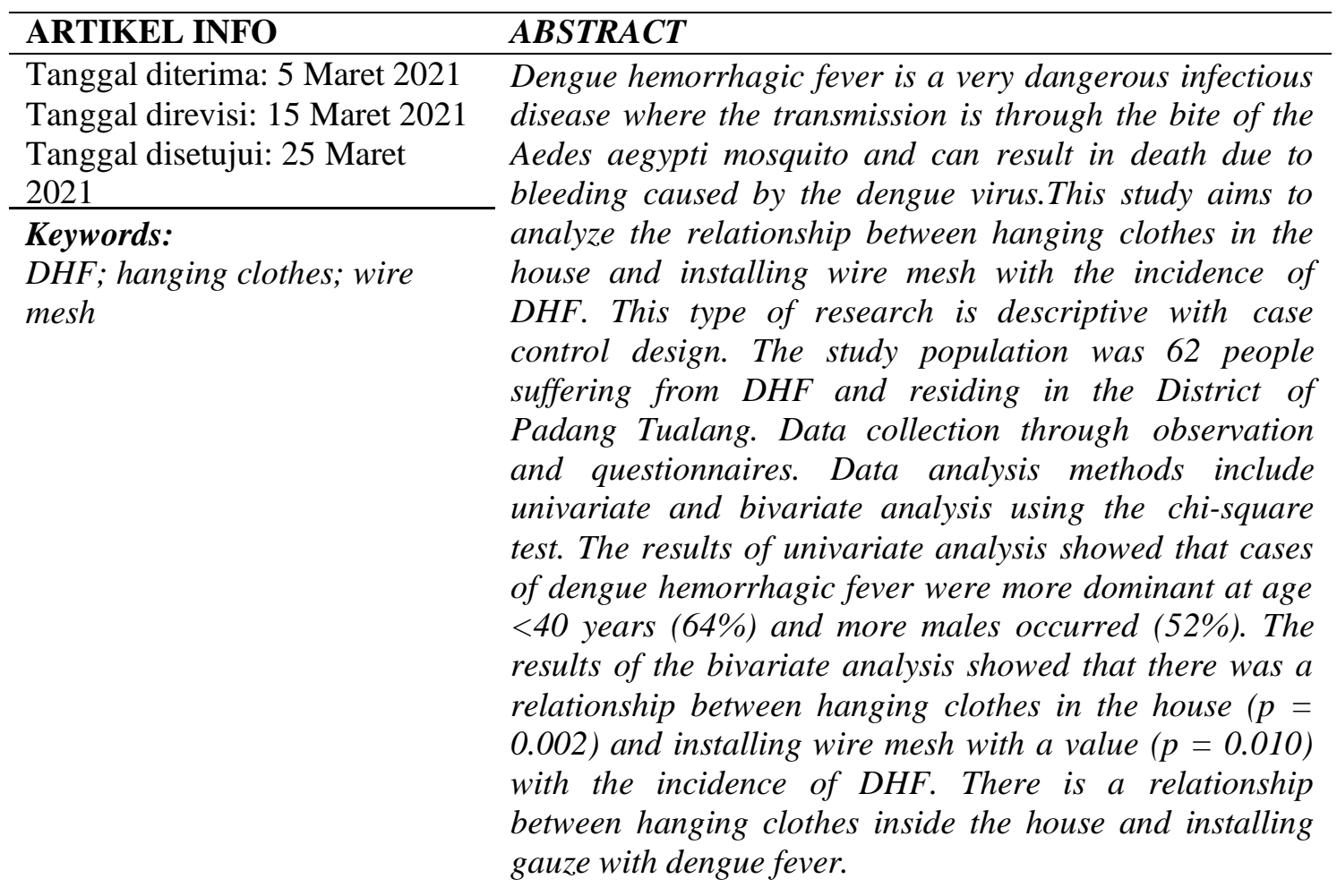

\section{ABSTRAK}

Demam Berdarah Dengue adalah penyakit menular yang sangat berbahaya dimana penularannya melalui gigitan nyamuk Aedes aegypti dan bisa mengakibatkan kematian akibat perdarahan yang disebabkan oleh virus dengue. Kabupaten langkat merupakan salah satu wilayah endemis DBD dengan urutan ketiga di Sumatera Utara. Penelitian ini bertujuan untuk menganalisis hubungan antara menggantung pakaian di dalam rumah dan memasang kawat kasa dengan kejadian DBD. Jenis Penelitian ini deskriptif dengan desain kasus kontrol. Populasi penelitian adalah masyarakat yang menderita DBD dan bertempat tinggal di Kecamatan Padang Tualang sejumlah 62 orang. Pengumpulan data melalui observasi dan kuesioner. Metode analisis data meliputi analisis univariat dan bivariat dengan menggunakan uji chi-square. Hasil analisis univariat menunjukkan bahwa kasus demam berdarah dengue lebih dominan terjadi pada umur $<40$ Tahun sebanyak (64\%) dan berjenis kelamin laki-laki 
Kata Kunci:

DBD; menggantung pakaian;

kawat kasa lebih banyak terjadi sebanyak (52\%). Hasil analisis bivariat menunjukkan bahwa ada hubungan antara menggantung pakaian di dalam rumah $(p=0,002)$ dan memasang kawat kasa dengan nilai $(p=0,010)$ dengan kejadian DBD. Ada hubungan antara menggantung pakaian di dalam rumah dan memasang kawat kasa dengan kejadian demam berdarah dengue.

\section{Pendahuluan}

Penyakit Demam Berdarah Dengue (DBD) termasuk penyakit menular yang sangat berbahaya dimana penularannya melalui gigitan nyamuk Aedes aegypti dan bisa mengakibatkan kematian akibat perdarahan yang disebabkan oleh virus Dengue (Sukohar, 2014). Dan merupakan salah satu penyakit yang dalam beberapa tahun terakhir telah menjadi masalah kesehatan internasional yang terjadi pada daerah tropis dan subtropis di seluruh dunia terutama daerah perkotaan dan pinggiran kota (Organization, 2015).

Setiap tahun, diperkirakan 390 juta infeksi dengue terjadi di seluruh dunia. Dari jumlah tersebut, sekitar 500.000 kasus berkembang menjadi demam berdarah yang parah atau demam berdarah dengue, suatu bentuk penyakit yang lebih parah yang mengakibatkan 25.000 kematian setiap tahun di seluruh dunia (Febiharsa et al., 2018).

Jumlah penderita DBD di Indonesia yang dilaporkan sebanyak 129.650 kasus dengan jumlah kematian sebanyak 1.071 orang (Insidance Rate (IR) per angka kesakitan 50,75 per 100.000 penduduk dan Case Fatality Rate (CFR) per angka kematian sebesar 0,83 persen). Dibandingkan tahun 2014 dengan kasus sebanyak 100.347 serta IR 39,80 terjadi peningkatan kasus pada tahun 2015. Kematian akibat DBD dikategorikan
Coresponden Author:

Email: syarifah.fadrina@gmail.com Artikel dengan akses terbuka dibawah lisensi

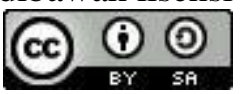

tinggi apabila CFR $>1 \%$ (Kemenkes RI, 2016).

Kabupaten Langkat merupakan salah satu wilayah endemis DBD dengan urutan ketiga di Sumatera Utara. Penyebaran penyakit diketiga wilayah tersebut begitu tinggikarena ketiga wilayah tersebut saling bersinggungan satu dengan yang lain. Hal ini menyatakan bahwa kasus DBD diduga mewabah di desa pantai cermin di tahun 2017 kecamatan tanjung pura kabupaten langkat sebanyak 29 Kasus. Penyebaran penyakit ini menewaskan seorang warga dan belasan warga lainnya menjalani perawatan medis di rumah sakit. Pada bulan februari 2019 juga dilaporkan bahwa penyakit ini juga menyerang warga dikecamatan wampu kabupaten langkat yang merupakan seorang pelajar, sementara satu pelajar yang sama diduga meninggal yang sebelumnya sudah mendapatkan perawatan disalah satu rumah sakit di medan.

Hasil penelitian dari (Suyasa, 2007), bahwa kondisi rumah dan lingkungan dapat beresiko menularkan penyakit terutama lingkungan. Lingkungan yang buruk sangat mendukung aktifnya dan berkembangnya vektor DBD. Lingkungan yang tidak sehat dapat beresiko terhadap perkembangbiakan dan penyebaran vektor DBD. Keberadaan vektor tersebut ditentukan oleh kepadatan penduduk dalam daerah, keberadaan tempat sampah yang tidak memenuhi syarat, tidak 
terdapat langit-langit, serta ditemukannya jentik nyamuk dalam ban bekas, keberadaan pot tanaman yang menggunakan lebih dari satu tempat penampungan air (TPA), dan kurangnya penggunaan kawat kasa pada ventilasi, kondisi yang seperti itu sangat potensial untuk tempat perindukan nyamuk Aedes aegypti (Handiny et al., 2020). Perilaku masyarakat yang masih kurang baik terhadap kondisi lingkungan seperti membiarkan sampah berserakan, air tergenang, tidak menguras tempat penampungan air, membiarkan tempat penampungan air terbuka, masih menggantung pakaian di dalam rumah dan tidak dilakukannya penaburan bubuk abate pada kamar mandi yang jarang di kuras.

Menurut (Pusdatin Kemenkes, 2017), bahwa cara yang efektif dan efisien untuk mengatasi kejadian DBD adalah dengan cara melakukan pemberantasan sarang nyamuk (PSN) yang merupakan salah satu kegiatan dalam perilaku hidup bersih dan sehat untuk mencegah penularan penyakit DBD. Departemen kesehatan mengadakan semboyan 3M dengan kegiatan antara lain mengurastempat penampungan air secara teratur, menutup tempat-tempat penampungan air dan mengubur barang-barang bekas yang dapat menjadi sarang nyamuk. Kegiatan tersebut sekarang berubah menjadi $3 \mathrm{M}$ plus yaitu memelihara ikan cupang pemakan jentik nyamuk, menaburkan bubuk abate pada bak tempat penampung air, setidaknya 2 bulan sekali, menggunakan obat nyamuk, menggunakan krim pencegah pengigitan nyamuk, melakukan pemasangan kawat kasa pada jendela atau ventilasi, tidak membiasakan menggantung pakaian dan dianjurkan memasang kelambu ditempat tidur. Rumusan masalah dalam penelitian ini untuk mengetahui penyebab terjadinya DBD berdasarkan aspek kesehatan lingkungan dengan cara menganalisis bagaimana hubungan antara memasang kawat kasa dan menggantung pakaian di dalam rumah dengan kejadian DBD di Kabupaten Langkat. Dan tujuan dari penelitian ini yaitu untuk menganalisis hubungan antara memasang kawat kasa dan menggantung pakaian di dalam rumah dengan kejadian Demam Berdarah Dengue (DBD) di Kabupaten Langkat.

\section{Metode Penelitian}

Penelitian ini merupakan penelitian Observasional Analitik dengan design penelitian kasus kontrol. Karena penelitian dilakukan untuk menganalisis hubungan antara memasang kawat kasa dan menggantung pakaian di dalam rumah dengan kejadian DBD di Kabupaten Langkat.

Populasi dalam penelitian ini adalah masyarakat yang menderita DBD yang bertempat tinggal di Kecamatan Padang Tualang berjumlah 62 orang. Populasi kasus adalah seluruh masyarakat yang bertempat tinggal di Kecamatan Padang Tualang yang pernah menderita DBD melalui diagnosa dokter dengan hasil laboratorium dan berdasarkan data Dinas Kesehatan Kabupaten Langkat periode Juli s/d Desember 2019 dan Januari 2020. Populasi control adalah seluruh masyarakat yang bertempat tinggal di Kecamatan Padang Tualang yang tidak pernah menderita DBD melalui diagnosa dokter atau dengan pemeriksaan dengue IgG/IgM serta hematokrit dan trombosit di laboratorium sejak 1 (enam) bulan terakhir periode Juli s/d Desember 2019 dan Januari 2020.

Sampel kasus dalam penelitian ini adalah penderita yang menderita DBD dengan gejala mendadak selama 2-7 hari melalui diagnose dokter dengan hasil laboratorium. Sampel kontrol dalam penelitian ini adalah penderita yang belum pernah menderita DBD melalui diagnose dokter dengan hasil laboratorium sejak 6 (enam) bulan terakhir dari bulan Juli-Desember 2019 dan Januari 2020. 
Hubungan Menggantung Pakaian dan Memasang Kawat Kasa dengan Kejadian Demam Berdarah dengue di Kabupaten Langkat

Metode pengumpulan data diperoleh dari wawancara dengan menggunakan kuesioner dan observasi. Analisis data adalahdilakukan dengan uji Chi-Square pada tingkat kepercayaan 95\%. Jika $\mathrm{p}<0,05$ maka terdapat adanya hubungan yang bermakna antara variabel independen dengan variabel dependen. Penelitian ini dilakukan pada bulan Maret 2020.

\section{Hasil dan Pembahasan}

\section{A. Hasil Penelitian}

\section{1) Keadaan Geografis}

Kabupaten langkat merupakan salah satu daerah yang berada di Sumatera Utara. Secara geografis Kabupaten Langkat pada $3^{\circ} 14^{\prime} 00^{\prime \prime}-$ $4^{\circ} 13^{\prime} 00^{\prime \prime}$ Lintang Utara, 97'52'00'98 45'00" Bujur Timur dan 4-105 m dari permukaan laut. Kabupaten Langkat menempati area seluas \pm $6.263,29 \mathrm{Km}^{2} \quad(626.329 \mathrm{Ha})$ yang terdiri dari 23 Kecamatan dan 240 Desa serta 37 Kelurahan Definitif. Area Kabupaten Langkat di sebelah Utara berbatasan dengan Provinsi Aceh dan Selat Malaka, di sebelah Selatan berbatasan dengan Kabupaten Karo, di sebelah Barat berbatasan dengan Provinsi Aceh, dan di sebelah Timur berbatasan dengan Kabupaten Deli Serdang dan Kota Pangkalan Susu. Berdasarkan luas daerah menurut kecamatan di Kabupaten Langkat, luas daerah terbesar adalah kecamatan Secanggang dengan luas $1.101,83 \mathrm{~km} 2$ atau 17,59 persen diikuti kecamatan Batang Serangan dengan luas 899,38 km2 atau 14,36 persen. Sedangkan luas daerah terkecil adalah kecamatan Pangkalan Susu dengan luas 42,05 km2 atau 0,67 persen dari total luas wilayah Kabupaten Langkat.

\section{2) Keadaan Demografi}

Jumlah penduduk Kabupaten Langkat, berdasarkan data Dinas Kependudukan dan Catatan Sipil Kabupaten Langkat Tahun 2016 sebanyak 1.271.454 jiwa. Terdiri dari laki-laki 651.121 jiwa dan perempuan 620.333 jiwa. Penduduk terbanyak berada di Kecamatan Stabat yaitu 83.093 jiwa, kemudian Kecamatan Selesai 70.035 jiwa, sedangkan Kecamatan dengan penduduk terkecil adalah Kecamatan Pematang Jaya dengan jumlah penduduk 13.102 jiwa.

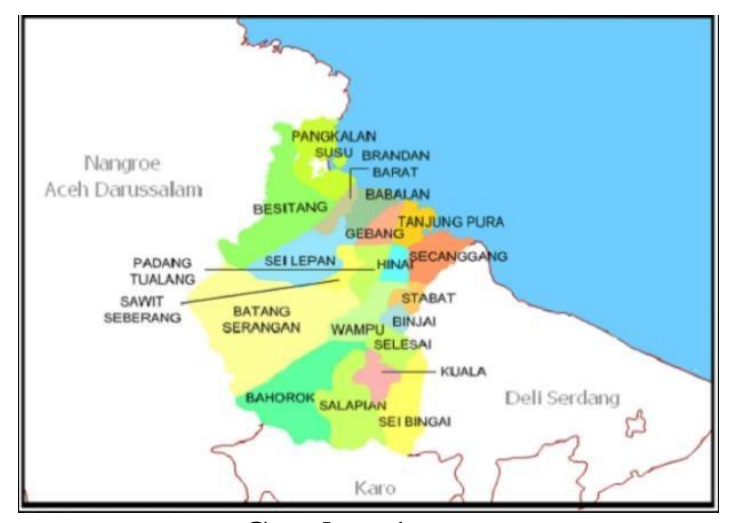

Gambar 1

Peta Administrasi Kabupaten Langkat Sumber: BPS Langkat, 2016

Tabel 1

Distribusi Frekuensi Karakteristik Responden

\begin{tabular}{ccccc}
$\begin{array}{c}\text { Karakteristik } \\
\text { Responden }\end{array}$ & Kasus & \multicolumn{3}{c}{ Kontrol } \\
\cline { 1 - 4 } & $\mathbf{N}$ & $\mathbf{\%}$ & $\mathbf{N}$ & $\mathbf{\%}$ \\
\hline Umur & & & & \\
\hline mh<40 Tahun & 16 & 64 & 10 & 40 \\
\hline = 40 Tahun & 9 & 36 & 15 & 60 \\
\hline Jumlah & $\mathbf{2 5}$ & $\mathbf{1 0 0}$ & $\mathbf{2 5}$ & $\mathbf{1 0 0}$ \\
\hline Jenis Kelamin & & & & \\
\hline Laki-laki & 13 & 52 & 16 & 64 \\
\hline Perempuan & 12 & 48 & 9 & 36 \\
\hline Jumlah & $\mathbf{2 5}$ & $\mathbf{1 0 0}$ & $\mathbf{2 5}$ & $\mathbf{1 0 0}$ \\
\hline & & & &
\end{tabular}

Berdasarkan tabel 1 pada variabel umur diketahui bahwa 
responden yang berumur $<40$ Tahun sebanyak 16 orang $(64.0 \%)$ dan yang berumur $\geq 40$ Tahun sebanyak 9 orang (36.0\%). Pada variabel jenis kelamin diketahui bahwa responden yang berjenis kelamin laki-laki yaitu sebanyak 13 orang $(52.0 \%)$ dan yang berjenis kelamin perempuan sebanyak 12 orang $(48.0 \%)$.

Tabel 2

\section{Distribusi Frekuensi Menggantung} Pakaian di Dalam Rumah

\begin{tabular}{ccccc}
\hline $\begin{array}{c}\text { Menggantung } \\
\text { Pakaian di } \\
\text { Dalam } \\
\text { Rumah }\end{array}$ & Kasus & \multicolumn{3}{l}{ Kontrol } \\
\cline { 1 - 5 } & $\mathrm{N}$ & $\%$ & $\mathrm{~N}$ & $\%$ \\
\hline Buruk & 20 & 80 & 8 & 32 \\
\hline Baik & 5 & 20 & 17 & 68 \\
\hline Jumlah & $\mathbf{2 5}$ & $\mathbf{1 0 0}$ & $\mathbf{2 5}$ & $\mathbf{1 0 0}$ \\
\hline
\end{tabular}

Berdasarkan tabel 2 pada variabel menggantung pakaian di dalam rumah responden dengan kategori buruk pada kelompok kasus sebanyak 20 orang $(80,0 \%)$ dan yang baik yaitu sebanyak 5 orang $(20,0 \%)$, pada kelompok kontrol yang buruk yaitu sebanyak 8 orang $(32,0 \%)$ dan baik yaitu sebanyak 17 orang $(68,0 \%)$.

Tabel 3

Distribusi Frekuensi Memasang Kawat

\begin{tabular}{lllll}
\multicolumn{3}{c}{ Kasa } & & \\
\cline { 1 - 4 } $\begin{array}{c}\text { Memasang } \\
\text { Kawat } \\
\text { Kasa }\end{array}$ & Kasus & \multicolumn{3}{c}{ Kontrol } \\
\cline { 1 - 4 } & $\mathrm{N}$ & $\%$ & $\mathrm{~N}$ & $\%$ \\
\hline Buruk & 19 & 76 & 9 & 36 \\
\hline Baik & 6 & 24 & 16 & 64 \\
\hline Jumlah & $\mathbf{2 5}$ & $\mathbf{1 0 0}$ & $\mathbf{2 5}$ & $\mathbf{1 0 0}$ \\
\hline
\end{tabular}

Berdasarkan tabel 3 pada variabel memasang kawat kasa responden dengan kategori buruk pada kelompok kasus sebanyak 19 orang $(76,0 \%)$ dan yang baik yaitu sebanyak 6 orang (24,0\%), pada kelompok kontrol yang buruk yaitu sebanyak 9 orang $(36,0 \%)$ dan baik yaitu sebanyak 16 orang $(64,0 \%)$.

\section{3) Analisis Bivariat}

\section{Tabel 4}

Hubungan Menggantung Pakaian Di

Dalam Rumah dan Memasang Kawat

Kasa Dengan Kejadian Demam

Berdarah Dengue Di Kbaupaten Langkat Tahun 2020

\begin{tabular}{|c|c|c|c|c|c|c|c|c|}
\hline \multirow{3}{*}{ Variabel } & \multicolumn{6}{|c|}{$\begin{array}{c}\text { Kejadian Demam Berdarah } \\
\text { Dengue }\end{array}$} & \multirow{3}{*}{$\begin{array}{c}\text { p. } \\
\text { val } \\
\text { ue }\end{array}$} & \multirow{3}{*}{$\begin{array}{c}\text { OR } \\
(95 \% \\
\text { CI })\end{array}$} \\
\hline & \multicolumn{2}{|c|}{ Kasus } & \multicolumn{2}{|c|}{$\begin{array}{r}\text { Kontr } \\
\text { ol } \\
\end{array}$} & \multicolumn{2}{|c|}{ Total } & & \\
\hline & $\mathbf{N}$ & $\%$ & $\mathbf{N}$ & $\%$ & $\mathbf{N}$ & $\%$ & & \\
\hline \multicolumn{9}{|l|}{ Umur } \\
\hline $\begin{array}{l}<40 \\
\text { Tahun }\end{array}$ & 16 & 61,5 & 10 & 38,5 & 26 & 100,0 & \multirow{2}{*}{$-0,157$} & \multirow{2}{*}{$\begin{array}{c}2,667 \\
(0,850- \\
8,366)\end{array}$} \\
\hline $\begin{array}{l}\geq 40 \\
\text { Tahun }\end{array}$ & 9 & 37,5 & 15 & 62,5 & 24 & 100,0 & & \\
\hline \multicolumn{8}{|l|}{$\begin{array}{l}\text { Jenis } \\
\text { Kelamin }\end{array}$} & \multirow{3}{*}{$\begin{array}{c}0,609 \\
(0,196- \\
1,891)\end{array}$} \\
\hline $\begin{array}{l}\text { Laki- } \\
\text { laki }\end{array}$ & 13 & 44,8 & 16 & 55,2 & 29 & 100,0 & \multirow{2}{*}{$-0,567$} & \\
\hline $\begin{array}{l}\text { Peremp } \\
\text { uan }\end{array}$ & 12 & 57,1 & 9 & 42,9 & 21 & 100,0 & & \\
\hline \multicolumn{8}{|c|}{$\begin{array}{l}\text { Menggantung Pakaian Di } \\
\text { Dalam Rumah }\end{array}$} & \multirow{3}{*}{$\begin{array}{r}8,500 \\
(2,338- \\
30,908)\end{array}$} \\
\hline Buruk & 20 & 71,4 & 8 & 28,6 & 28 & 100,0 & \multirow{2}{*}{$-0,002$} & \\
\hline Baik & 5 & 22,7 & 17 & 77,3 & 22 & 100,0 & & \\
\hline \multicolumn{8}{|c|}{$\begin{array}{l}\text { Memasang } \\
\text { Kawat Kasa } \\
\end{array}$} & \multirow{3}{*}{$\begin{array}{c}5,630 \\
(1,648- \\
19,232)\end{array}$} \\
\hline Buruk & 19 & 67,9 & 9 & 32,1 & 28 & 100,0 & \multirow{2}{*}{$-0,010$} & \\
\hline Baik & 6 & 27,3 & 16 & 72,7 & 22 & 100,0 & & \\
\hline
\end{tabular}

Berdasarkan tabel 4 diketahui bahwa hasil analisis menunjukkan tidak ada hubungan umur dengan kejadian demam berdarah dengue dengan nilai $p=0,157 \quad(p>0,05)$. Hasil analisis menunjukkan bahwa tidak ada hubungan jenis kelamin dengan kejadian demam berdarah denguedengan nilai $p=0,567(p>0,05)$.

Hasil analisis menunjukkan bahwa ada hubungan menggantung pakaian di dalam rumah dengan kejadian demam berdarah dengue dengan nilai $p=0,002$. 
Hubungan Menggantung Pakaian dan Memasang Kawat Kasa dengan Kejadian Demam Berdarah dengue di Kabupaten Langkat

\section{B. Pembahasan}

\section{Karakteristik Responden Berdasarkan Umur}

Pada variabel umur diketahui bahwa responden yang berumur $<40$ Tahun sebanyak 26 orang $(52.0 \%)$ dan responden yang berumur $\geq 40$ Tahun sebanyak 24 orang $(48.0 \%)$. Berdasarkan hasil analisis hubungan antara umur dengan kejadian demam berdarah dengue diketahui bahwa tidak ada hubungan antara umur dengan $(p<0,05)$ dan nilai OR sebesar 8,500 $(95 \%$ $\mathrm{CI}=2,338-30,908)$, artinya bahwa menggantung pakaian di dalam rumah yang buruk berpeluang 8,5 kali terkena DBD dibanding dengan yang baik.

Hasil analisis menunjukkan bahwa ada hubungan memasang kawat kasa dengan kejadian demam berdarah dengue dengan nilai $p=0,010(p<0,05)$ dan nilai OR sebesar 5,630 (95\% CI=1,648-19,232), artinya bahwa yang tidak memasang kawat kasa berpeluang 5,6 kali terkena DBD dibanding dengan yang memasang kawat kasa.

kejadian demam berdarah dengue dengan nilai $p=0,157(p>0,05)$. Menurut hasil penelitian (Hastuti, 2009) menunjukkan bahwa penyakit DBD tidak menyerang pada kelompok usia tertentu dan dapat menyerang semua usia baik balita, anak-anak, maupun orang dewasa.

\section{Karakteristik Responden Berdasarkan Jenis Kelamin}

Pada variabel jenis kelamin diketahui bahwa responden yang berjenis kelamin laki-laki yaitu sebanyak 29 orang $(58.0 \%)$ dan yang berjenis kelamin perempuan sebanyak 21 orang $(42.0 \%)$.Berdasarkan hasil analisis hubungan antara jenis kelamin dengan kejadian demam berdarah dengue diketahui bahwa tidak ada hubungan antara jenis kelamin dengan kejadian demam berdarah dengue dengan nilai $\mathrm{p}=0,567(\mathrm{p}>0,05)$. Berdasarkan hasil penelitian ini diketahui bahwa laki-laki maupun perempuan bisa saja terkena demam berdarah dengue dan apabila dikaji lebih dalam setiap orang mempunyai peluang untuk menderita demam berdarah dengue tergantung dari faktor-faktor yang dapat berisiko terhadap demam berdarah dengue (Kurniawati, 2014).

3. Hubungan Menggantung Pakaian di Dalam Rumah dengan Kejadian Demam Berdarah Dengue di Kabupaten Langkat

Pada variabel menggantung pakaian di lama rumah diketahui bahwa yang perilaku yang buruk dalam menggantung pakaian lebih banyak pada kelompok kasus yaitu sebanyak 20 orang $(71,4 \%)$ dan yang perilaku baik lebih banyak pada kelompok kontrol yaitu sebanyak 17 orang $(77,3 \%)$. Sehingga terdapat hubungan antara menggantung pakaian di dalam rumah dengan kejadian DBD dengan nilai $p=0,002$ dan nilai OR adalah $8,500(95 \%$ CI 2,338-30,908) yang berarti variabel menggantung pakaian di dalam rumah mempunyai risiko 8,500 kali untuk terjadi kejadian DBD kepada rumah tangga yang tidak menggantung pakaian di dalam rumah.

Hasil ini berbeda dengan teori yang ada yaitu bahwa nyamuk Aedes aegypti menyenangi hinggap pada benda-benda yang tergantung seperti: pakaian, kelambu atau tumbuhtumbuhan di dekat tempat berkembangbiaknya, dan dalam ruangan yang agak gelap serta lembab (RI, 2012). Nyamuk Aedes aegypti lebih menyukai beristirahat di tempat yang gelap, lembab, tempat tersembunyi di dalam rumah atau bangunan, termasuk kolong tempat tidur, kloset, kamar mandi dan dapur. Selain itu juga bersembunyi pada benda-benda yang digantungkan seperti baju, tirai, dan 
dinding (RI, 2014). Ada kemungkinan hasil ini terjadi karena ada faktor lain yang mempengaruhi, seperti adanya bendabenda tergantung lain yang tidak masuk dalam definisi operasional, tetapi menjadi tempat yang dihinggapi nyamuk, seperti tirai atau gorden dan pakaian yang digantung dalam keadaan bersih tetapi berwarna gelap.

4. Hubungan Memasang Kawat Kasa dengan Kejadian Demam Berdarah Dengue di Kabupaten Langkat

Pada variabel memasang kawat kasa diketahui bahwa yang tidak memasang kawat kasa lebih banyak pada kelompok kasus yaitu sebanyak 19 orang $(67,9 \%)$ dan yang perilaku baik memasang kawat kasa lebih banyak pada kelompok kontrol yaitu sebanyak 16 orang $(72,7 \%)$ (Ayun, 2015). Sehingga terdapat hubungan antara memasang kawat kasa dengan kejadian DBD dengan nilai $p=0,010$ dan nilai OR adalah 5,630 (95\% CI=1,648-19,232), artinya bahwa yang tidak memasang kawat kasa berpeluang 5,6 kali terkena DBD dibanding dengan yang memasang kawat kasa.

Memasang kawat nyamuk (kasa) pada pintu, lubang jendela, dan ventilasi di rumah serta menggunakan kelambu juga merupakan upaya pencegahan gigitan nyamuk demam berdarah (Frida, 2020). Hasil perhitungan uji chisuare, didapat $p$ value $0,003<0,05$ maka Ho ditolak, dan Ha diterima, sehingga ada hubungan antara memasang kawat kasa dengan kejadian DBD.

Penelitian ini sejalan dengan penelitian (Adyatma \& Ibrahim, 2011) di Kelurahan Tidung Kecamatan Rappocini Kota Makasar menunjukkan bahwa terdapat hubungan antara kepemilikan ventilasi berkasa terhadap kejadian demam berdarah dengue di masyarakat.

Pada penelitian ini bahwa di lapangan banyak ditemukan yang sedikit meggunakan kawat kasa, berbagai hal yang menyebabkan kurangnya minat responden untuk memasang jawat kasa pada setiap ventilasi antara lain adalah kurang mengetahui fungsi dari kawat kasa, besarnya biaya yang harus dikeluarkan dan menurut mereka lebih besar manfaat memasang kawat kasa besi pada setiap ventilasi dari pada memasang kawat kasa. kurangnya minat pada kelompok kasus untuk memasang kawat kasa yang dapat menyebabkan seringnya terjadi kontak antara penghuni rumah dengan nyamuk Aedes aegypti, sehingga penelitian ini membuktikan bahwa memasang kawat kasa memiliki hubungan dengan terjadinya kejadian DBD.

\section{Kesimpulan}

Kesimpulan yang di dapat dalam penelitian ini adalah Ada hubungan antara menggantung pakaian di dalam rumah dan memasang kawat kasa dengan kejadian DBD di Kabupaten Langkat.

\section{BIBLIOGRAFI}

Adyatma, A., \& Ibrahim, E. (2011). Hubungan Antara Lingkungan Fisik Rumah, Tempat Penampungan Air Dan Sanitasi Lingkungan Dengan Kejadian Dbd Di Kelurahan Tidung Kecamatan Rappocini Kota Makassar. Makassar: Jurnal Fkm Universitas Hasanuddin.

Ayun, L. L. (2015). Hubungan Antara Faktor Lingkungan Fisik Dan Perilaku Dengan Kejadian Demam Berdarah Dengue (Dbd) Di Wilayah Kerja Puskesmas Sekaran, Kecamatan Gunungpati, Kota Semarang Tahun 2015. Universitas Negeri Semarang.

Febiharsa, D., Sudana, I. M., \& Hudallah, N. (2018). Uji Fungsionalitas (Blackbox Testing) Sistem Informasi Lembaga Sertifikasi Profesi (Silsp) Batik Dengan Appperfect Web Test Dan Uji 
Hubungan Menggantung Pakaian dan Memasang Kawat Kasa dengan Kejadian Demam Berdarah dengue di Kabupaten Langkat

Pengguna. Joined Journal, 1(2), 117126.

Frida, N. (2020). Mengenal Demam Berdarah Dengue. Alprin.

Handiny, N. F., Km, M., Gusni Rahma, S. K. M., Epid, M., Rizyana, N. P., \& Km, M. (2020). Buku Ajar Pengendalian Vektor. Ahlimedia Book.

Hastuti, A. T. (2009). Hubungan Antara Persepsi Masyarakat Tentang Menguras, Mengubur, Dan Menutup (3m) Dengan Pencegahan Demam Berdarah Dengue (Dbd) Di Desa Selokerto Kecamatan Sempor Kabupaten Kebumen. Jurnal Ilmiah Kesehatan Keperawatan, 5(2).

Kemenkes Ri. (2016). Profil Kesehatan Indonesia Tahun 2015. In Jakarta: Kementerian Kesehatan Republik Indonesia.

Kurniawati, R. (2014). Analisis Spasial Sebaran Kasus Demam Berdarah Dengue Di Kabupaten Jember Tahun 2014.

Organization, W. H. (2015). Who Report On Global Surveillance Of Epidemic-Prone Infectious Diseases: Dengue And Dengue Haemorrhagic Fever, 2014 [Cited 2014 Jul 21].

Pusdatin Kemenkes, R. I. (2017). Data Dan Informasi Profil Kesehatan Indonesia 2016. Kementerian Kesehatan Republik Indonesia, 164.

Ri, K. K. (2012). Petunjuk Teknis Pemberantasan Sarang Nyamuk Demam Berdarah Dengue (Psn Dbd) Oleh Juru Pemantau Jentik (Jumantik). Depkes Ri, Jakarta.

Ri, K. K. (2014). Data, Pedoman Pengumpulan Dokumen, Pengisian. Balitbangkes.
Sukohar, A. (2014). Demam Berdarah Dengue (Dbd). Jurnal Medula, 2(02).

Suyasa, I. N. (2007). Gede Dkk, 2007. Hubungan Faktor Lingkungan Dan Perilaku Masyarakat Dengan Keberadaan Vektor Demam Berdarah Dengue (Dbd) Di Wilayah Kerja Puskesmas I Denpasar Selatan. Politeknik Kesehatan Denpasar Jurusan Kesehatan Lingkungan. Vol. 3 (1): 1- 6. 